\title{
A Comparative Cost Analysis of Undergraduate Business Degrees for International Students in Selected Countries
}

\author{
Shilpa Iyanna (Corresponding author) \\ College of Business Administration, Abu Dhabi University \\ PO box 59911, Abu Dhabi, UAE \\ Tel: 971-2-501-5664Ｅ-mail: shilpa.iyanna@adu.ac.ae \\ Jaya Abraham \\ College of Business Administration, Abu Dhabi University \\ PO box 59911, Abu Dhabi, UAE \\ Tel: 971-2-501-5892Ｅ-mail: jaya.abraham@adu.ac.ae
}

Received: November 3, 2011

Accepted: December 5, 2011 Published: February 16, 2012

doi:10.5539/ijbm.v7n4p145

URL: http://dx.doi.org/10.5539/ijbm.v7n4p145

\begin{abstract}
International student enrolments are an increasingly important part of global higher education. Research indicates that the cost of education is an important factor which influences the students' choice of study destination. Given the rising cost of education, a comparative analysis of the cost of education is likely to give certain countries a competitive edge. The primary focus of this paper is to compare the cost of undergraduate business education in countries competing for a share in the international student market. Data for this paper was drawn from a range of published secondary sources and includes tuition fees, living costs and visa expenses as these components are considered unavoidable for international students. Findings from this study suggest that Malaysia and the UAE have an advantage over the other competing countries in terms of cost. The paper concludes with implications for universities and policy makers and directions for further research.
\end{abstract}

Keywords: International students, Undergraduate business degrees, Cost of education, US, UK, Australia, New Zealand, Canada, Malaysia and UAE

\section{Introduction}

The global higher education landscape has been affected dramatically by international student movement with an increasing number of students going abroad for tertiary education, i.e., university level education or vocationally oriented education. In 2008, it was estimated by the OECD (Organization for Economic Cooperation and Development) that over 3.3 million tertiary students were enrolled outside their country of citizenship. Over the past three decades, the number of international students has grown substantially, from 0.8 million worldwide in 1975 to 3.3 million in 2008, a more than four-fold increase (OECD 2010).

Reporting on the trends on international student movement, Verbik (2007) states that traditionally most international students enrolled in institutions belonging to the OECD with the main destinations being the US, UK, Australia, Germany and France. More recently however, the US, UK and Australia have all experienced a decline or slump in international student enrolment, nevertheless, they are likely to remain an increasingly competitive market for the foreseeable future. In 2005, Japan, Canada and New Zealand together attracted approximately $13 \%$ of the international student market. However, Verbik's report indicates that these countries have experienced declining international enrolments and have become less significant destinations for transnational higher education (HE). New players in Asia and the Middle East have entered the international student market. In 2006, for instance, Malaysia, Singapore and China had a combined share of $12 \%$ of the global student market with somewhere between 250,000 to 300,000 students enrolled in tertiary education (Verbik 2007). The newest entrant into the global student market seems to be the United Arab Emirates (UAE). The UAE government spends close to $25 \%$ of its budget on education. Emphasis is being laid on creating quality infrastructure for education, as well as linking education and skill development to complement the global 
standards of education. As an emerging hub for international students, the UAE offers a unique learning environment which blends a mosaic of world cultures and nationalities without any kind of discrimination. As a result, an increasing number of top international learning centres have already been attracted to UAE to open their campuses, in addition to many private institutions. According to recent estimates the UAE is the largest host of international branch campuses globally, having over 40 providers (Wilkinson 2010). The diversified system of education in the UAE is aimed at attracting students from the region who are unable to go abroad to study. Thus, the UAE higher education sector is slowly becoming a competitor to countries such as China, Singapore, and the Kingdom of Saudi Arabia (Mahani, et. al. 2011). The next section will review the factors that influence international student destination choice.

There is an extensive body of literature on the factors that might influence the choice of study destination (see Abbott and Ali 2005; Mazzarol and Soutar 2002; Chaoshin et al. 2001; Chaoshin and Ken 2000). Mazzarol and Soutar (2002) posit that six factors influence student's choice of study destination - first was the overall level of knowledge and awareness of the destination country in the student's home country. The second factor was the level of referrals or personal recommendations that the study destination receives from parents, relatives, friends and others prior to making the final decision. The third factor related to cost issues, including the cost of fees, living expenses, travel costs and social costs, such as crime, safety and racial discrimination. The fourth factor was the environment, which related to perceptions about the study "climate" in the destination country, as well as its physical climate and lifestyle. The fifth factor was geographic proximity, which related to the geographic (and time) proximity of the potential destination country to the student's country. The sixth factor was social links, which related to whether a student has family or friends living in the destination country and whether family and friends have studied there previously. Thus, although choice of study destination is influenced by a number of factors, Ali (2008) reports that the cost of education is the main factor which influences the students' choice of study destination.

Literature on the impact of cost of education on destination choice however is not very extensive (Ali and Subramaniam 2010). Also, there is a lack of comparable data and statistical analyses in this sector (Verbik 2007). Therefore it is important to examine the relative costs in competing countries.

To this end the primary focus of this paper is to compare the cost of education in countries competing for a share in the international student market, namely US, UK, Australia, Canada, New Zealand, Malaysia, and UAE. As the cost of education varies across disciplines, degrees and duration, this paper will focus on the cost of education for an undergraduate business degree in the countries chosen for this study. A focus on business degrees was considered appropriate as Pfeffer and Fong (2002) posit that not only have business school enrolments soared, they are the success story of late twentieth-century education. For instance, "in 1955-56, graduate business education was virtually nonexistent, with only 3,200 MBA degrees awarded in the U.S. By 1997-98 however, this number had grown to over 102,000" (Zimmerman, 2001: 3). In the spring of 2001, 92\% of all accredited colleges and universities, offered an undergraduate major in business (U.S. News and World Report, 2002). In 1996-1997, more than a quarter million undergraduate degrees in business were awarded (AACSB Newsline, 1999). In addition new business education programs were started, and existing programs have expanded and grown in the U.S. as well as around the world. For instance, "the number of business schools in Britain has risen from 20 in the early 1980s to 120" (The Economist, 1996: 54), while business education has spread throughout Asia and continental Europe.

In light of the above discussion this paper will start with a brief review of the education system in the countries chosen for this study. Next, the data collection method is described. This is followed with a comparative cost analysis of the various components that are included in the cost of education. Finally the conclusions with policy implications are presented.

\section{Education system of the selected countries}

\subsection{United States of America}

The US has more than 3,900 colleges and universities offering a wide range of undergraduate degree programs. The schools offer either a two-year degree called an associate degree or a four-year degree called a bachelor's degree in a specific course of study. Admission criteria include the student's GPA scores in addition to standardized test scores such as TOEFL or SAT test scores. In the US, private institutions set their own international tuition fees although the fees in the public universities will be significantly lesser than the private universities (USA Study Guide, 2010). 


\subsection{United Kingdom}

Higher education institutions in UK are independent, self-governing bodies active in teaching, research and scholarship. Higher education (HE) is provided by many different types of institution. In addition to universities and university colleges, publicly funded higher education provision is available in some colleges of further education. The most common qualification for entry to higher education is the General Certificate of Education at 'Advanced' (A) level. Other appropriate NQF level 3 qualifications may also provide entry to HE. Tuition fees are set at different levels for home/EU and international students. The tuition fee (for domestic/EU students at least) is capped at a maximum rate, which effectively means that most institutions charge exactly the same amount. Universities set their own international student fees and the British government legislation allows the universities to charge more for international students.

\subsection{Australia}

The Australian higher education system consists of independent, self-governing public and private universities and higher education institutions that award higher education qualifications. There are 37 public universities and 2 private universities in Australia. Requirements for admission to all programs are set by individual universities. Admission to undergraduate programs is usually based on successful completion of a total of 13 years of school education though some institutions use interviews, portfolios or demonstrated aptitude and most provide alternative pathways for mature-age (non-school leaver) students. International tuition fees reflect full costs and there are no government imposed quotas on the number of international students.

\subsection{Canada}

The system of education in Canada can be noted for the absence of a federal system. There are 95 public universities and several private not-for-profit universities. The environment, the quality of education and the job opportunities available are strong factors attracting students to Canada. Admissions requirements vary depending on the country and/or educational curriculum of international students. In some cases international students may need a study permit or a temporary resident visa, before applying for a study permit. The fee for international students is set by individual institutions and abides by government policies.

\subsection{New Zealand}

More than half of the eight universities in New Zealand are ranked among the top 500 universities of the world. A bachelor's degree in New Zealand takes three years. One more year of study leads to an Honours degree. Entry to most universities is open to anyone who meets the qualification prescribed by New Zealand Qualifications Authority (NZQA). Education is partially subsidized for national students. The international students can seek educational loans and scholarships for their education in New Zealand.

\subsection{Malaysia}

The Malaysian Government provides $60 \%$ of the tertiary education, with the private sector providing the balance of $40 \%$. Many of the private institutions offer courses in cooperation with a foreign institutes or universities, especially in the United States, the United Kingdom and Australia, allowing students to spend a portion of their course duration abroad in the parent institute. These unique collaborative Bachelor's degree programs include 'advance standing' arrangement, American degree credit transfer programs, ' $2+1$ ' twinning degree and $3+0$ franchised degree programs. The general entry requirement for the undergraduate studies is STPM (Sijil Tinggi Persekolahan Malaysia), which is the Malaysian High School Certificate qualification or pre-university program or its equivalent depending on the country and/or educational curriculum of international students. Studying in private colleges and universities in Malaysia is usually more expensive than the government-funded institutions.

\subsection{United Arab Emirates}

The UAE has established a diversified system of higher education in a very short period of time. The Ministry of Higher Education and Scientific Research (MOHESR) established the Commission for Academic Accreditation (CAA) to promote educational excellence across diverse institutions of higher learning in the UAE. The higher education institutions can be divided into three categories: public, private, and global partnerships. There are 3 public universities, 9 private universities and a host of institutions that have global partnerships/ derivations. Requirements for admission to all programs are set by individual universities. UAE nationals can attend public institutions free of charge. Tuition fees in other institutions are calculated per credit hour and are the same for citizens, expatriates and foreign students.

\section{Data collection methodology}

Data for this paper was drawn from a range of published secondary sources such as websites, Education Ministry, 
statistics from education consultants, OECD indicators, and other documented statistics from various countries and UNESCO. Data presented in this paper regarding the cost of education includes tuition fees, living costs and visa expenses as these components are considered unavoidable for international students. Tuition fees and living expenses were collected from a sample of business schools ranked by Eduniversal (note1). Eduniversal provides a comprehensive country wise ranking of universities using a system of Palmes, where 5Palmes refers to business schools with major international influence; 4Palmes refer to business schools that are internationally known; 3Palmes refer to business schools that are nationally strong and/or with continental links; 2Palmes refer to business schools with strong regional influence; and 1 Palme refer to business schools with strong local influence. The sample consisted of approximately $10 \%$ of all the universities ranked by Eduniversal for a particular country, which were chosen randomly (see Table 1 and appendix for details).

\section{Insert Table 1-here}

Cost was first collected from individual university websites in the local currency and then converted to US Dollar for comparative purposes (see appendix for details). Visa costs were collected from the embassies and/or consulates of representative countries in the UAE. Costs indicated in this study are based on averages. The exchange rate was taken on $7^{\text {th }}$ September, 2011.

\section{Cost of education - comparative analysis}

The cost of education includes various components such as tuition fees, living costs, cost of educational materials such as text books, medical costs, visa cost and other expenses. Among these tuition fees, living costs and visa cost are considered unavoidable for a student enrolled outside his/her country of citizenship. Thus this paper considers the total cost of education as the sum of tuition fees, living costs and visa cost.

\subsection{Tuition fees}

Findings indicate that tuition fees for undergraduate business degrees vary across institutions within a country and across countries. Findings are presented in Table 2.

\section{Insert Table 2-here}

Tuition fees data indicates that universities in Malaysia charge the lowest fees while US universities charge the highest tuition fees. Tuition fees in UAE universities are less than half of those charged by US universities. Australian undergraduate business degrees are less expensive compared to US. The degrees from UK and New Zealand are closely clustered. Thus with reference to tuition fees, Malaysia has an advantage over the major destinations such as US, UK, Canada and New Zealand and UAE.

\subsection{Living costs}

Living costs are defined as the money spent on items such as accommodation, transportation, food, telephone and other miscellaneous items. The data on annual living costs is drawn from the websites of various universities. It has to be noted however, that living costs are difficult to estimate because they are dependent on lifestyle. The average living costs are presented in Table 3.

\section{Insert Table 3-here}

According to the data presented in Table 2, living costs are the highest in UK and this is followed very closely by Australia, while Malaysia offers the lowest living cost. Living costs in other destinations such as US, Canada and New Zealand are closely clustered and while UAE offers the second lowest living costs to an international student. Table 2 indicates that in terms of living costs Malaysia has an advantage over the other countries compared in this study.

\subsection{Visa cost}

Visa cost refers to the cost involved in obtaining permission for international students to travel to, enter, or remain in a particular country. Students need to obtain the visa before travelling to the destination country. In Malaysia however, the government does not allow student visa stamping outside the country. Therefore prospective students have to travel to Malaysia on a tourist visa. On arrival at the university stamping of the student visa will be undertaken by the university authorities. The visa cost for the various countries are presented in Table 4.

\section{Insert Table 4-here}

Findings indicate that visa cost is the highest for Australia followed by UK. The cost of student visa for Canada, UAE and US are closely clustered, while Malaysia has an advantage with the lowest visa cost for international students. 


\title{
4.4 Total cost of education
}

As indicated earlier, total cost of education has been computed as the sum of tuition fees, living costs and visa cost. The total cost is presented in Table 5.

\author{
Insert Table 5-here
}

Total cost comparisons indicate that US business undergraduate degrees are the most expensive with a total of $\$ 41396$. Australian universities offer the second-most expensive undergraduate business education. Canada and UK have a competitive advantage compared to US and Australia, while New Zealand has an advantage over all the above. Total cost of education is the lowest in Malaysia, followed by UAE. Thus in terms of total cost of education, Malaysia is the most competitive.

\section{Conclusion, Implications and Further Research}

The competition in the global higher education landscape is getting more and more intense. Research has indicated that the cost of education is a major influence on study destination choice. Findings from this study suggest that Malaysia and UAE have an advantage over the other competing countries in terms of the cost of education.

Malaysia and the UAE, (1) provide unique collaborative degrees from the US, UK, Australia and Canada which are globally recognized and accepted; and (2) have global campuses of internationally recognized universities (e.g. University of Wollongong in Dubai; University of Nottingham in Malaysia). This implies that students can earn an American degree or an Australian degree in Malaysia or the UAE. The cost advantage of getting these degrees in Malaysia or the UAE could influence destination choice. The findings thus lend support to Verbik's (2007) report that Asia and Middle East are now emerging as new destinations for international students.

The 2010 estimates of the composition of the Malaysian GDP by sector is as follows: agriculture (10.5\%), industry (41.4\%), and services i.e. tourism, financial services and retail (48.2). While the composition of the UAE GDP by sector is as follows: agriculture $(0.9 \%)$, industry $(53 \%)$, and services i.e. banking, insurance and retail (46.1\%). The findings from this study suggest that the education sector has the potential of becoming an important contributor the country's GDP in these countries. As tuition fees in Malaysia and UAE are lower than the other competing countries, institutional and national student recruitment strategies could benefit by emphasizing and highlighting this cost advantage. This could lead to an increase in international student enrolments.

A limitation of the current study is that the focus is on cost of education for undergraduate business degrees only. An area worthy of further research is to extend this study to analyze the cost of education in different streams, e.g. medicine, engineering, law etc. Further research also needs to examine the impact of financial scholarships on international student enrolment. In addition, future research should include other factors that influence destination choice and could create country-wise comparative index of the same.

\section{References}

AACSB Newsline. (1999). Number of undergraduate business degrees continue downward plunge, while MBA degrees awarded skyrocket. Doctoral degrees on the decline. [Online] Available: http://www.aacsb.edu/publications/printnewsline/index.asp (August 20, 2011)

Abbot, M., \& Ali. E. (2005). The Impact of Exchange Rate and the University Reputation on the Destination of International Students. Working Paper (No.13, School of International Studies, New Zealand). [Online] Available: http://www.crie.org.nz/research-papers/Abbott-Ali.pdf (August 20, 2011)

Ali. E. (2008). The Impact of Exchange Rate Variations on the Destinations International Students. Economic Bulletin, 9, 1. Universiti Teknologi MARA, Malaysia. [Online] Available: http://rmi.uitm.edu.my/images/stories/JEB/Vol9/bej\%20v\%209\%201.pdf (August 20, 2010)

Ali. E., \& Subramaniam, G. (2010). Analysis of Cost of International Education in Selected Countries. Business Management Quarterly Review, 1(3), 50-63.

Chaoshin, C et al. (2001). Market Liberalization and Exchange Rate Exposure: The Case of Taiwanese Exporting Firms. Economia Internationale, 54(2), 137-161.

Chaoshin, C., \& Ken, H. (2000). Exchange Rate Exposure of Taiwanese Exporting Firms. Review of Pacific Basin Financial Markets and Policies, 3(2). 201-234. http://dx.doi.org/10.1142/S0219091500000133

Mahani, S., \& Molki, A (2011). Internationalization of Higher Education: A Reflection on Success and Failures among Foreign Universities in the United Arab Emirates. Journal of International Education Research, 7(3), 1-8. 
Mazzarol, T., \& Soutar, G. N. (2002). "Push-pull" factors influencing international student destination choice. International Journal of Educational Management, 16(2), 82-90. http://dx.doi.org/10.1108/09513540210418403

Pfeffer, J., \& Fong, C.T. (2002). The End of Business Schools? Less Success than Meets the Eye. Academy of Management Learning and Education, 1(1), 78-95. http://dx.doi.org/10.5465/AMLE.2002.7373679

The Economist (1996). Dons and Dollars. July 20, pp.53-54.

U.S. News and World Report. (2002). Top Business Schools 2002, U.S. News and World Report.

USA Study Guide. (2010). [Online] Available: http://www.usastudyguide.com/ (August 20, 2011)

Verbik, Line. (2007). International Student Mobility: Patterns and Trends. In World Education News and Reviews, World Education Services, New York.

Wilkinson, S. (2010). Higher Education in United Arab Emirates: An Analysis of Outcomes of Significant Increases in Supply and Competition. Journal of Higher Education Policy and Management, 32(4), 389-400. http://dx.doi.org/10.1080/1360080X.2010.491112

Zimmerman, J. L. (2001). Can American business schools survive?. Unpublished manuscript, Simon Graduate School of Business Administration, Rochester, New York.

\section{Notes}

Note 1. Eduniversal was established in 2008 to provide students, professionals and academics with a universal perspective on higher education. It allows prospective students and their parents to choose the best institution giving their career and their means, wherever they live, and wherever they'd wish to go. http://www.eduniversal-ranking.com/

Note 2. Winner of the Sheikh Khalifa Excellence Award, 2011. http://www.skea.ae/index.htm http://www.adu.ac.ae/en/news/abu-dhabi-university-receives-the-sheikh-khalifa-excellence-award.html

Table 1. Total number of Universities Ranked by Eduniversal and sample chosen for this study

\begin{tabular}{|c|c|c|c|c|c|c|c|}
\hline \multirow{2}{*}{ Country } & \multicolumn{6}{|c|}{ Total number of Universities Ranked by Eduniversal } & \multicolumn{2}{c|}{$\begin{array}{c}\text { Sample } \\
\text { used in this } \\
\text { study }\end{array}$} \\
\cline { 2 - 8 } & $\begin{array}{c}5 \\
\text { Palmes }\end{array}$ & $\begin{array}{c}4 \\
\text { Palmes }\end{array}$ & $\begin{array}{c}3 \\
\text { Palmes }\end{array}$ & $\begin{array}{c}2 \\
\text { Palmes }\end{array}$ & 1 Palme & Total & 16 \\
\hline US & 27 & 55 & 67 & 5 & - & 154 & 6 \\
\hline UK & 7 & 15 & 26 & 2 & - & 50 & 35 \\
\hline Australia & 5 & 6 & 15 & 9 & - & 35 & 4 \\
\hline Canada & 6 & 10 & 9 & 1 & - & 26 & 4 \\
\hline New Zealand & 2 & 3 & 2 & 1 & - & 8 & 2 \\
\hline Malaysia & - & 1 & 3 & 2 & - & 6 & 4 \\
\hline UAE & - & - & 3 & 1 & - & 4 & \\
\hline
\end{tabular}

Table 2. Average tuition fees for 2011-2012

\begin{tabular}{|c|c|}
\hline Country & Annual tuition fees (US \$) \\
\hline US & 29,952 \\
\hline UK & 18,492 \\
\hline Australia & 23,541 \\
\hline Canada & 21,898 \\
\hline New Zealand & 17,572 \\
\hline Malaysia & 12,031 \\
\hline UAE & 13,746 \\
\hline
\end{tabular}


Table 3. Average living costs for 2011-2012

\begin{tabular}{|c|c|}
\hline Country & Annual living costs (US \$) \\
\hline US & 11,304 \\
\hline UK & 15,513 \\
\hline Australia & 15,237 \\
\hline Canada & 10,070 \\
\hline New Zealand & 10,835 \\
\hline Malaysia & 2,950 \\
\hline UAE & 7,328 \\
\hline
\end{tabular}

Table 4. Visa cost for 2011-2012

\begin{tabular}{|c|c|}
\hline Country & Visa Cost ( US \$) \\
\hline US & 140 \\
\hline UK & 415 \\
\hline Australia & 565 \\
\hline Canada & 130 \\
\hline New Zealand & 177 \\
\hline Malaysia & 62 \\
\hline UAE & 136 \\
\hline
\end{tabular}

Table 5. Total cost of education for 2011-2012

\begin{tabular}{|c|c|c|c|c|}
\hline Country & Tuition fees & Living costs & Visa cost & $\begin{array}{c}\text { Total cost of } \\
\text { education }\end{array}$ \\
\hline US & 29,952 & 11,304 & 140 & 41,396 \\
\hline UK & 18,492 & 15,513 & 415 & 34,420 \\
\hline Australia & 23,541 & 15,237 & 565 & 39,343 \\
\hline Canada & 21,898 & 10,070 & 130 & 32,098 \\
\hline New Zealand & 17,572 & 10,835 & 177 & 28,584 \\
\hline Malaysia & 12,031 & 2,950 & 62 & 15,043 \\
\hline UAE & 13,746 & 7,328 & 136 & 21,210 \\
\hline
\end{tabular}


Appendix 1: Sample Details

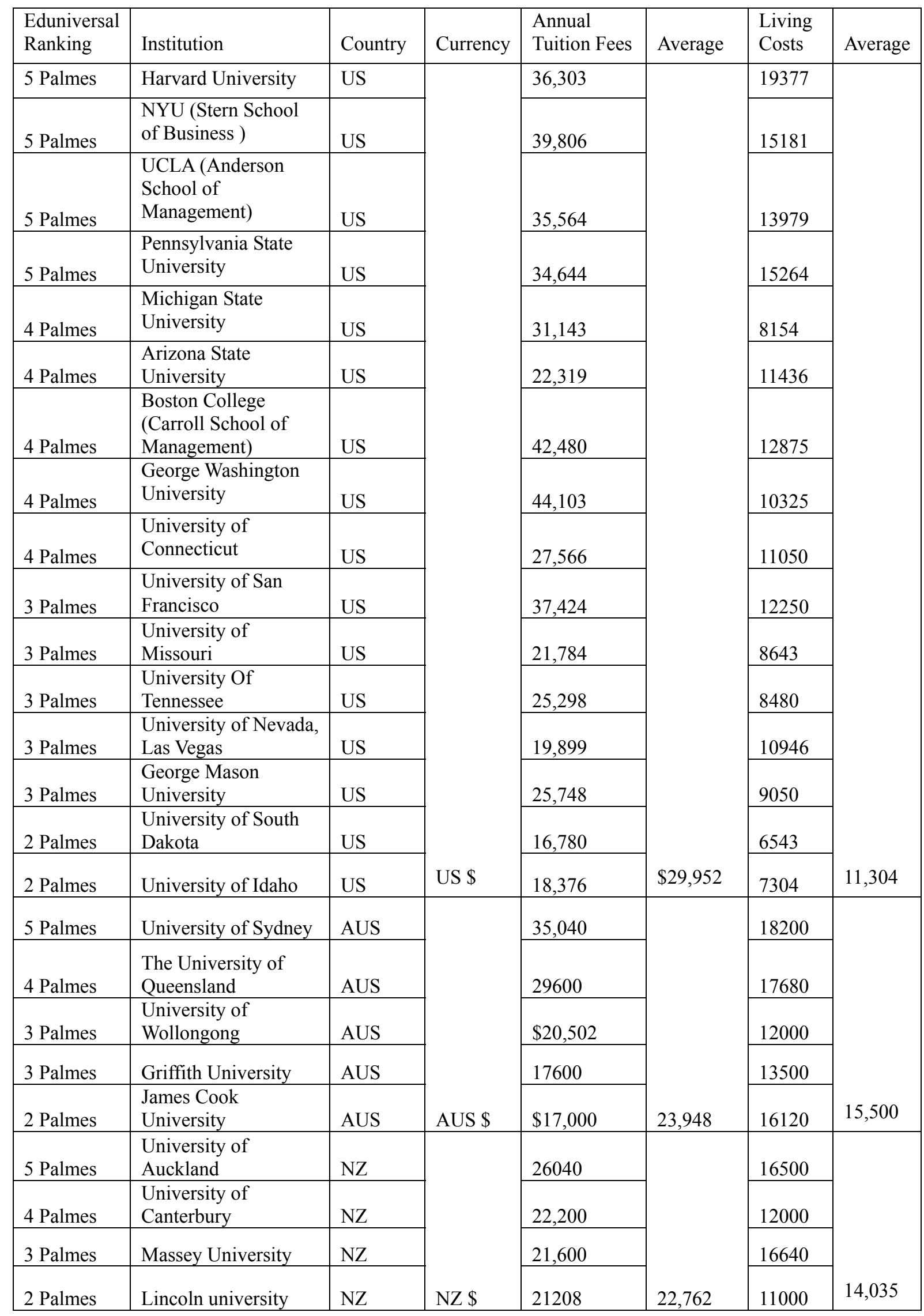




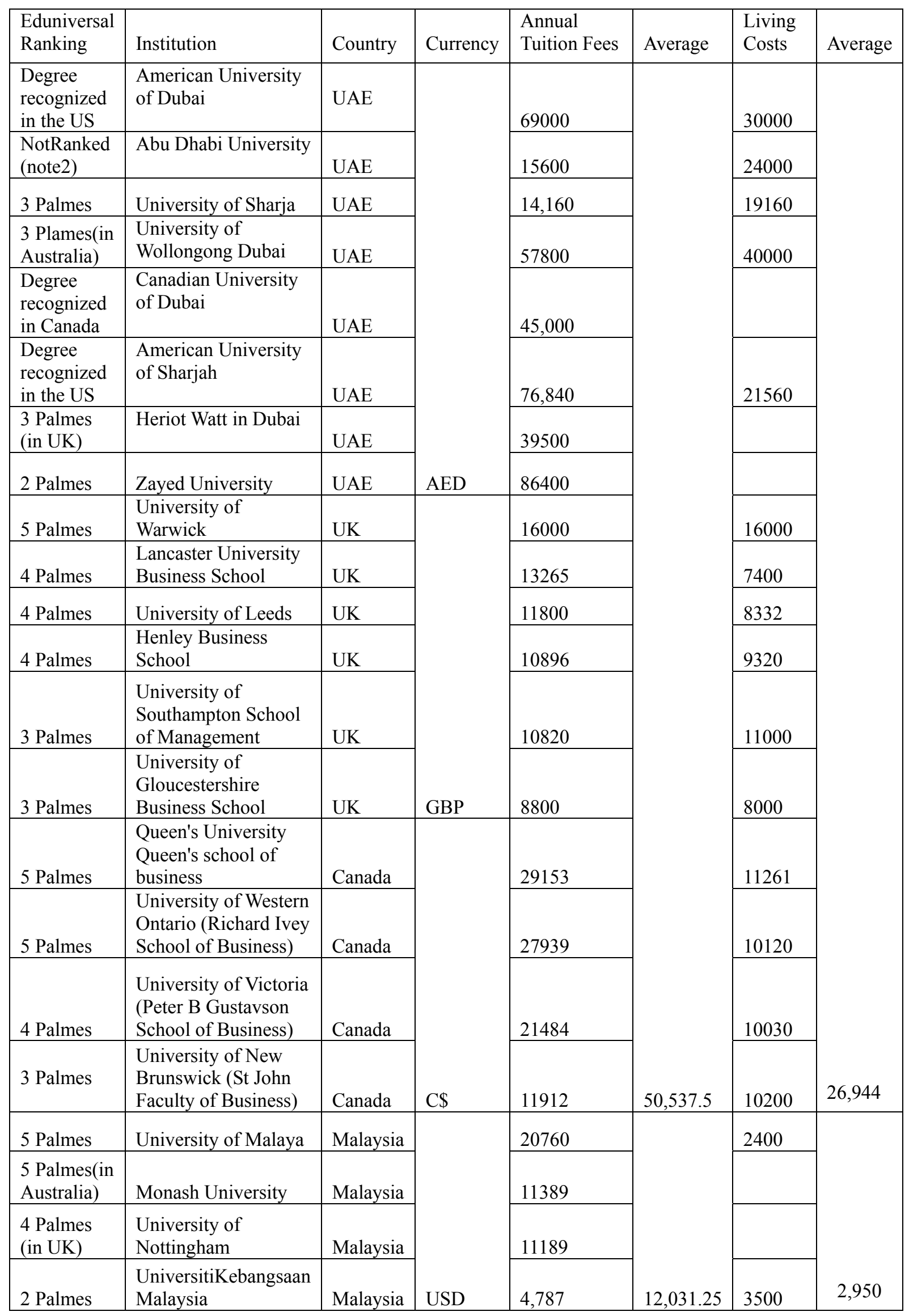

